\title{
Multinational Company CEO Roles as Public Relations in Host Country (Case Study PT Samsung Electronics Indonesia)
}

\author{
Roswita Oktavianti ${ }^{1}$, Lusia Savitri Setyo Utami ${ }^{2}$ \\ Faculty of Communication, Universitas Tarumanagara, Indonesia ${ }^{1,2}$ \\ \{roswitao@fikom.untar.ac.id ${ }^{1}$, lusias@fikom.untar.ac.id $\left.{ }^{2}\right\}$
}

\begin{abstract}
CEOs or business leaders of multinational companies have different communication strategies in every country. The strategy is based on the public characteristics in the host countries. The communication strategy done by the CEOs represents the company and have a potential to build reputation. In this case, the CEOs of the multinational company has a communication strategy such as public relations. This research aims to know the communication strategy done by the CEOs of multinational companies in Indonesia in optimizing the function of PR. The interview result and its analysis show that multinational companies have broad and competitive communication strategy. The broad communication strategy refers to following the rule from the headquarter, while competitive communication strategy refers to the characteristics in the host country. However, CEOs of multinational companies also have broad communication strategy that is more flexible by paying attention to companies' interest in the host countries. This way aims to build positive reputation of the company in the host country.
\end{abstract}

Keywords: communication strategy; public relations; multinational company; headquarter; host country

\section{Introduction}

Multinational companies have different strategies in building reputation in every country. This is because every country has different public characteristics. The process of maintaining or rebuilding the reputation becomes significant, especially when the company is on its critical condition. The head of the company plays a big role in the process of rebuiling the company's reputation. The head of the company becomes the main figure or the culture's icon [1]. The role of the head in building the company'd reputation was also shown by the CEO of Air Asia, Tony Fernandes, when Air Asia QZ8501 went down in Pangkalan Bun, Central Kalimantan, Indonesia, in 2014. For some days, Tony directly appeared to check and accompany the process of handling the remains and consoling the victims' families [2]

When there is crisis, the CEO does the PR strategy. Public Relations are people who helps frame, implement, manage, and communicate the policy that set how the institution interacts with the public [4]. PR has nine functions [5] or strategies [1] which are publicity or media relations; promotion or selling; community relations; government relations; public 
information; special events; issues management, reputation management, crisis communications; employee relation; and lobbying. The conflict between organizations and pressure groups can be prevented if the PR professionals play they role by making sure that there is two-way communication between organizations and the involved groups. In other words, there is a mediation. The management skill that is done by the head is an intangible asset. The ex CEO of Quaker Oats, John Stuart, said that intangible assets are more important than the tangible assets such as properties, factories, and equipment [3].

The existence of the head of company will create publicity. In fact, mass media tend to post statements from main sources. Publicity or media relations get the media cover from the news release, press conference, and other sources. The pioneer and the PR practitioner at once, Ivy Ledbetter Lee, stated that companies must open for public and media in delivering either good or bad news [5].

The role of the head or CEO as public relations and marketing has been mostly reviewed and researched. Men et al., researched the Facebook feed of companies' CEOs by using content analysis. The result showed that CEOs used dialogic principle in Facebook to increase public interaction. However, one-way of information strategy is still frequently used. This fact shows that there are two kinds of leadership communications, which are dialogic communication in internet media and leadership communication in public relations [6].

On the other hand, Cottan-Nir and Lehman-Wilzig conducted a research about CEO as company's branding figure that at first was not noticed and designed by CEOs. The research showed that the company's stakeholder had reputation on brands. This research even suggested other researchers to learn about other types of CEOs in other countries or cultures [7]. This research is conducted to figure out the communication strategies of the heads of multinational companies as public relations in host countries. Strategies are ways to accomplish the goals and purposes of the organization. Strategies also mean as the direction which the organization determines to reach its missions. In an organization, there is a broad strategy for the whole organization and the competitive strategy is only used for particular event. On the other hand, functional strategy directly contributes on the competitive strategy [1].

The executives of companies who have progressive thought will hardly work for making and having open communication strategy naturally and truly for their audience target [8]. The target audience is a description of receiver of messages, that is usually used in advertising, marketing, and PR. Public is the receivers in the communication process between the sender and receiver. The term 'target audience' is commonly used in advertising, marketing, and Public Relations. Audience means a group of people that must be communicated, while public means people that are influenced by issues [9].

\section{Method}

This research used qualitative approach. The aim of this approach is to understand or explain the behaviour and belief, the identification process and to understand the contexts from people's experiences. This approach is the better way to get deep and holistic understanding about the relation between international culture and communication from the perspective of society or ethnic groups [10].

The researcher used case study as the strategy of the research. The research question is how the communication strategy done by the CEOs of multinational companies is in building the reputation of companies in Indonesia. According to Yin, the research question "how" and 


\begin{abstract}
"why" refer to an explanatory study so that the tendency is focused more on the case study. A case study is applied to explain contemporary events, but the actions are not manipulated. A case study involves facts starting from documents, artifacts, interviews, and observation [11].

The researcher used primary sources in the form of deep interviews. The interview was done to the Vice President of PT Samsung Electronics Indonesia, Lee Kang Hyun. Samsung itself is one of multinational companies in Indonesia. The researcher also implemented secondary sources which were documents, some news about the informants, and news about the company in national mass media. The unit of analysis in this research was individual actions or activities in implementing public relations strategy in multinational companies. Unit of response in this research was heads of multinational companies.
\end{abstract}

\title{
3 Result and Discussion
}

Public from Public Relations division of a company is including internal and external public. Internal public includes the employees and their families, as well as company's management. While external public includes consumers, communities, society, government, mass media, suppliers, banks, etc[4].

\subsection{CEO Roles as PR}

\section{a) $\mathrm{CEO}$ as Spokesmen}

The informant becomes Vice President of PT Samsung Electronics Indonesia and the spokesman of Samsung in Indonesia at once. The first reason is because the informant stays in Indonesia longer, since 1993. Secondly, the informant has better understanding about the electronic industry of Samsung in Indonesia, either in selling or factories. Thirdly, the president, as a spokesman is sensitive to get fired from the headquarter if he is wrong in giving information, so that the president must be careful in talking to the reporters. The role of being a spokesman is given more to the vice president. Fourthly, the informant used to have other positions in Indonesia, which were the chair of Indonesia's Electronics Association, the chair of Chamber of Commerce and Korean Industry in Indonesia, and the vice chair of Electronic Association. This fact triggers the reporters to know the informant better. If there are common issues such as the development of Indonesia, or suggestions and criticism for the government, then the informant asks the reporters to quote with a role as the spokesman of the association. In opposite, if there is information related to Samsung, then the informant plays a role as the spokesman of Samsung.

\section{b) Communication with The Headquarter.}

There is a guideline that must be obeyed by the CEOs as spokesmen when stating information to the reporters or mass media. The list of "do" and "do not" or "permitted" and "unpermitted" information to say to reporters must be obeyed by all spokesmen and Public Relations of Samsung all around the world. Statements or issues that must not be conveyed to the reporters are numbers such as company turnover and revenue; offending competitors, and investment. In about to give response to reporters, the informant asks Public Relations to check the information first. Therefore, the statements that are delivered by the CEOs as spokesmen have been agreed by public relation division, including the agreement from the 
headquarter. However, in some cases the informant makes decisions by himself without the approval from the headquarter. For instance, in order to maintain the good relationship with Indonesia's government, Samsung Indonesia becomes a sponsor in some events. While on the other part, there is a rule related to sponsorships from the headquarter.

\section{c) Communication with Reporters}

There are different treatments in giving statements to journalists from national mass media and the ones from international mass media. Informants are more careful in delivering statements to journalists from international mass media. It is because the scope of the news is broader and more global, so that it raises possibilities to create big news that will influence the company's stock. In opposite, reporters from Indonesia's mass media have national scope so that the reporting has less global impacts. Meanwhile, informants must also be careful in delivering statements to journalists from national mass media because of some reasons: journalists are sometimes writing news without confirming; writing wrong news without revising; and the limited background, insight, and knowledge. The relationship with journalists is not only about news and reporting, but also personal and long-term relationship. Yet, the relation is not strong anymore as in 1990s and early 2000. At that time, Samsung Indonesia consistently did the approach to hold events with journalists. Now Samsung has controlled 50 percent of cellphone markets in Indonesia so that the relationship with journalists is only to giving responses or opinions about certain issues.

\section{d) Communication with PR Team}

Informants emphasize a point of teamwork with PR team of the company. The informants ask the PR to check the truth of the news, make press release, and hold press conference. The PR team reports to the CEOs the news that must be checked every morning and evening. However, there is a job desc that cannot be wholly delegated to PR team of the company, especially the ones that are related to communities and government.

\section{e) Communication with Community and Government}

Informants as the CEOs build the relationship with communities through Corporate Social Responsibility (CSR). Samsung is now focusing on CSR activities. The example is giving a washing machine for the refugees of natural disasters. The informants do not give that job to the staffs, instead, he was directly help the refugees. To get the activity published in mass media, the informants invite some journalists of the capital city, Jakarta, and gather local journalists. Another activity that cannot be delegated is the relationship with the government, especially in crisis. The explosion of a Samsung cellphone in other countries also gives impact to Indonesia. Many media in Indonesia discuss issues about a prohibition for passengers of government airline who brought those types of Samsung cellphones. To relieve the report, the informant calls and meets the government authorities directly. It aims to make Samsung get the official letter on deletion of the prohibition, and the related authorities announce the deletion of the prohibition to the public.

\subsection{Broad Strategy}

In multinational companies, the broad strategy is managed by the headquarter. Pearce and Robinson called it as grand strategies, which means a long-term comprehensive plan from 
essential actions where a company tries to accomplish its main goal. One of the solutions to achieve the goals is by pointing spokesmen of the company in the country where multinational companies develop their business. In a research on multinational companies in Kenya, it was found that multinational companies led by local directors are more able in adopting strategies that is adjusted with the host country. Therefore, a director plays an important role in the strategies of multinational companies that are adopted in the host countries [12].

Based on the analysis, the CEOs that is selected as a spokesman by the headquarter stays in a long period and has better understanding the culture of the host countries. In addition, a spokesman is chosen because he knows all topics. Executives of the company are not only able to plan but also knows the products and markets [13]. Multinational companies have regulations or guidelines related to communication with journalists or mass media. The regulation must be obeyed by all CEOs and spokesmen in all countries. It is in line with the basic characteristic of the world' transactional system, which is tendency of internationalisation and concentration on the financial capital and production [14]. The role of subsidiary company abroad is limited, which is to gather and sell products and implement the plans and policies that are developed in the headquarter [15]. The CEOs of multinational companies in host countries understand the core of the regulations. Meanwhile, other regulations are dominated by Public Relations of companies. Therefore, the CEOs confirm every statement and news to the Public Relations first. Professional PRs and PR consultants give advices to the CEOs and the top level management to supervise and measure the performance [1].

\subsection{Competitive Strategy}

A company using a global strategy means that it is controlled by the headquarter [14]. However, the director or the CEO needs to pay attention to the need of the target markets as an adaptation strategy with the environment of the host countries [12], or "think global, act local" [1]. A head and a spokesman at once of a multinational company in host countries have treatments that are adjusted with the characteristics of journalists as human resources. Multinational companies need to follow different strategies and structures in managing the relationship with resources in host countries [15]. PRs need to make decisions about the adjustment between strategies of certain media and its relevance with different channels and programs [16]. The characteristic of reporting by journalists of national/domestic media is different from the international media. International media have broader scope of news so that it gives impact to stock company. In opposite, the impact of reporting by journalist from local media. However, journalists of local media often write news without confirming, the limited background about the issues, even wrong news, and without revising again. As a PR, executives of the company that have progressive mind will try to construct and have an open communication strategy naturally and correctly for their audience [8].

\section{a) Publicity and Media Relations}

PRs do the publicity strategy or media relations [5]. In this research, the CEOs of the multinational companies has double roles. Besides becoming a representative of the company, he also plays a role as a spokesman of the association. The head implements the approach of human brands. The approach of human brands in business can be done in two ways, which are first, personal branding as a tool to increase career as employees or businessmen; second, CEO brands as a marketing and communication tool for the importance of the company [7]. When 
delivering criticism and suggestions to the government about the development of economics in host countries, the CEOs optimize their role as spokesmen of the association. The courage to deliver the opinion is triggered by the identity as foreigner. On the other hand, if there is a direct relation with the companies, then the CEOs will use their identity as the heads of the company. In multinational companies, a strategy of media relations depends on the fulfilment of the selling target of the company in host countries. If the selling is still low, then the heads must try to get the coverage in media. If the company will launch their products, they using strategy of media relations such as news release, live report in televisions, making events with journalists, press briefing, and personal relationship with journalists. In contrast, when the selling in host countries is already high, then the strategy of media relations can be directed to Corporate Social Responsibility (CSR) to build or maintain the company's reputation. The release of new products is done by holding press conference, while the press broadcast can only be done when there is crisis.

\section{b) Community Relation}

Community relation is an activity designed to strengthen the relationships between organizations and communities that have strategic interest [9]. The way to do it is by working with communities and communities of interest to influence public's attitude and policies [5]. The relation with communities becomes the focus of multinational companies that have achieved or even exceeded the selling target in host countries. The aim is to create positive reputation in government and the target audience in the host countries. The CEO and PR team bring journalist from the capital city (the location of the host countries' official office) and invite local reporters (the location of communities) to make the program that becomes a social responsibility of the company (Corporate Social Responsibility) get publicity. This activity is not delegated to PR team since journalists tend to publish and quote official sources based on strata. Strata are translated into the spokesmen of the government and industry, but generally the term refers to people or communities as official sources that produce information specifically for the headlines [17].

\section{c) Governmental Relations}

PR helps or influences the actions of central or local government in cases that involve legislation, regulation, and other related activities [5]. This can also be called as public affairs strategy that includes not only the governmental relations but also diplomacy, lobbying or fund raiser, third party intervention, foreign affairs, pressure groups, global sustainability, and legal/control frameworks [1]. In this research, the CEOs of multinational companies in host countries must make decisions that are contradictory with the instructions from the headquarter. It is because the company's head in host countries is responsible for the relationship between the company and local government. Multinational companies become official sponsors of governmental events in host countries. The decision is made by considering the request from the local government. Even though it is prohibited by the headquarter, the CEOs must decide by paying attention to the sustainability of the company in host countries.

Government plays a significant role in determining the easiness of getting inside the market through the regulation of safety and environment, price and incentive regulation, and the protection of local industry from international competition [13]. If multinational companies have had good relationship with the government, then the easiness of running a 
company and facing crisis will be attained. When there is crisis in a company and support from governmental institutions is needed, the CEOs of the company will meet the head of related governmental institution directly to deliver the official statements. This job must be done directly by the head, it cannot be delegated to PR team. By having a good relationship with the head of governmental institution, the crisis can be handled easily. In this case, the head decides a strategy for his company based on his belief [7].

\section{Conclusion}

CEOs or the head of multinational companies must implement communication strategy that fits the characteristics of host countries. They use broad strategy that is determined by the headquarter, while on the other hand they also use competitive strategy that is specifically applied in host countries. In creating publicity as well as promoting, CEOs of multinational companies consider the regulations determined by the headquarter and the characteristics of public in host countries at once. The public is including journalists, mass media, communities, and government. The form of publicity and promotion itself is changing as the increase of the target of product or service selling in host countries. Meanwhile, in building relationships, communication strategy which is implemented is adjusted to public's characteristics in host countries. It is because the relationship will define the sustainability of multinational companies in host countries. Sometimes in building this kind of relationship, multinational companies must negate the regulations set by the headquarter.

\section{References}

[1] S. Oliver, Public Relations Strategy, Third Edit. London: Kogan Page, 2010.

[2] A. Faizal, "Tony Fernandes : Kami Bertanggung Jawab Penuh atas Jatuhnya AirAsia QZ8501,” Kompas.com, 2014. [Online]. Available: https://nasional.kompas.com/read/2014/12/30/20511501/Tony.Fernandes.Kami.Bertan ggung.Jawab.Penuh.atas.Jatuhnya.AirAsia.QZ8501.

[3] K. L. Keller, Strategic Brand Management Building, Measuring, and Managing Brand Equity, 4th Editio. Essex: Pearson, 2012.

[4] R. Kriyantono, Public Relations Writing, Teknik Produksi Media Public Relations dan Publisitas Korporat. Jakarta: Prenada Media Group, 2008.

[5] D. Straubhaar, Joseph, LaRose, Robert, Lucinda, Media Now: Understanding Media, Culture and Technology Seventh Edition, Seventh Ed. Belmont, CA: Wadsworth Cengage Learning, 2012.

[6] L. R. Men, W. H. S. Tsai, Z. F. Chen, and Y. G. Ji, "Social presence and digital dialogic communication: engagement lessons from top social CEOs," J. Public Relations Res., vol. 30, no. 3, pp. 83-99, 2018.

[7] O. Cottan-Nir and S. Lehman-Wilzig, "CEO Branding: Between Theory and Practice - Case Studies of Israeli Corporate Founders,” Int. J. Strateg. Commun., vol. 12, no. 2, pp. 87-106, 2018.

[8] P. Argenti, Corporate Communications, Third Edit. Boston: Mc Graw Hill, 2003.

[9] K. Butterick, Pengantar Public Relation. Jakarta: PT Raja Grafindo Persada, 2014.

[10] A. Hennink, Monique M, Hutter, Inge, Bailey, Qualitative Research Methods. California: Sage Publications, 2011. 
[11] R. K. Yin, Case Study Research Design \& Methods, Third Edit. California: Sage Publications, 2003.

[12] M. Ogutu and C. M. Samuel, "Strategies Adopted By Multinational Corporations to Cope With Competition in Kenya," DBA Africa Manag. Rev., vol. 2, no. 3, pp. 69-82, 2012.

[13] G. D. Harreil and R. O. Kiefer, "Multinational Market Portfolios in Global Strategy Development," Int. Mark. Rev., vol. 10, no. 1, pp. 60-72, 1993.

[14] V. T. Guback, Thomas, Transnational Communication and Cultural Industries. Paris: UNESCO, 1982.

[15] F. A. Shah, "A Critical Review of Multinational Companies, Their Structures and Strategies and Their Link with International Human Resource Management," IOSR J. Bus. Manag., vol. 3, no. 5, pp. 28-37, 2012.

[16] R. Brown, Public Relations and The Social Web: How to Use Social Media an Web 2.0 in Communications. London: Kogan Page, 2009.

[17] R. K. Bivens, "The internet, mobile phones and blogging: How new media are transforming traditional journalism," Journal. Pract., vol. 2, no. 1, pp. 113-129, 2008. 